\title{
PENGARUH PENGEMBANGAN KARIER TERHADAP KEPUASAN KERJA KARYAWAN PADA RITEL ALFA MART DI MALANG
}

\author{
Lilis Nur Aini ${ }^{1}$, Tatiana Kristianingsih ${ }^{2}$, Fullchis Nurtjahjani ${ }^{3}$ \\ ${ }_{1,2,3}$ Politeknik Negeri Malang \\ lilisna@polinema.ac.id ${ }^{1}$, tatiana@polinema.ac.id ${ }^{2}$,nurfullchis@polinema.ac.id ${ }^{3}$
}

(Artikel diterima: Mei 2020, diterima untuk terbit: Juni 2020)

\begin{abstract}
Abstrak - Penelitian ini mengambil tema faktor penentu kepuasan kerja. Dalam penelitian ini diambil sampel 50 orang sebagai karyawan Alfamart. Studi kuantitatif di mana responden diperoleh dari kuesioner yang dibagikan digunakan sebagai data primer diolah dengan SPSS. Respon responden menilai rentang $1-5$, dengan skala likert sangat tidak setuju hingga sangat setuju. Berdasarkan hasil penelitian, dari uraian data mayoritas responden berjenis kelamin laki-laki dengan usia dibawah 25 tahun. Uji coba yang dilakukan adalah uji validitas dan reliabilitas yaitu uji validitas kuesioner yang dibagikan, uji t untuk menguji kebenaran hipotesis yang dirumuskan, uji korelasi dan regresi untuk menguji hubungan dan pengaruh hubungan dan pengaruh masing-masing variabel segmentasi pasar hubungan konsumen yang merupakan pengembangan karir. Pada uji coba yang dilakukan terdapat kebenaran hipotesis yang dirumuskan yaitu terdapat hubungan yang signifikan antara faktor pengembangan karir dengan kepuasan kerja.
\end{abstract}

Kata-kata kunci: Alfamart, kepuasan kerja, pengembangan karir

\section{Pendahuluan}

Semakin ketat persaingan dunia bisnis di era globalisasi saat ini. Diikuti dengan pesatnya perkembangan teknologi, sistem informasi, dan ilmu pengetahuan mengakibatkan kemampuan dan keunggulan mereka dengan mengerahkan seluruh potensi yang ada. Mereka dituntut untuk lebih inovatif dan kreatif dalam mengelola perusahaanya agar dapat bertahan dalam dunia bisnis.

Bisnis ritel di Indonesia mengalami perkembangan yang pesat pada beberapa tahun terakhir ini, dengan berbagai macam format serta jenisnya, akibat adanya perkembangan usaha manufaktur dan peluang pasar yang cukup terbuka, maupun upaya pemerintah untuk mendorong perkembangan bisnis ritel. Pemerintah berperan dalam melakukan perlindungan terhadap ritel nasional melalui: peraturan pemerintah dan undang-undang.

Dalam suatu organisasi tentu terdapat suatu tujuan yang ingin dicapai.Salah satu faktor yang mendukung dalam pencapaian tujuan adalah kepuasan kerja.Untuk mewujudkan tujuan tersebut diperlukan sumber daya manusia yang handal dan berdedikasi.Hal tersebut dipengaruhi oleh kepuasan kerja.Kepuasan kerja merupakan salah satu faktor yang sangat penting untuk mendapatkan hasil kerja yang optimal. Ketika seorang merasakan kepuasan dalam bekerja tentunya ia akan berupaya semaksimal mungkin dengan segenap kemampuan yang dimilikinya untuk menyelesaikan tugas pekerjaannya. Dengan demikian produktivitas dan hasil kerja pegawai akan meningkat secara optimal, secara otomatis sumber daya manusia akan meningkat dan akan merasakan adanya kepuasan kerja dengan sendirinya.

Faktor lain yang berpengaruh terhadap kepuasan kerja adalah pengembangan karier. Dengan adanya pengembangan karier yang baik maka karyawan akan merasa termotivasi sehingga menciptakan rasa puas dalam melaksanakan pekerjaan. Dengan adanya program pengembangan karier, dapat lebih meningkatkan dorongan atau motivasi kepada karyawan untuk lebih berprestasi dan memberikan kontribusi yang maksimal kepada perusahaan. Hal ini terjadi dikarenakan bahwa motivasi seseorang akan timbul apabila pengembangan karier yang ada disebuah perusahaan sudah ada dan jelas untuk dapat dilaksanakan. Keberhasilan pengembangan karier ditentukan oleh beberapa factor yaitu keterampilan selama belajar, keahlian, pelatihan ulang, kemampuan mendapatkan pekerjaan secara berkesinambungan dan keberhasilan psikologis

Kepuasan kerja karyawan akan mendorong terwujudnya pengembangan karier melalui perencanaan karier dan manajemen karier. Perencanaan karier adalah proses melalui individu pegawai mengidentifikasi dan mengambil langkah-langkah untuk mencapai tujuan-tujuan kariernya. Perencanaan karier melibatkan pengidentifikasian tujuan-tujuan yang berkaitan dengan karier dan penyusunan rencana-rencana untuk mencapai tujuan tersebut. Manajemen karier adalah proses melalui organisasi, menilai, menugaskan dan mengembangkan para pegawainya guna menyediakan sekumpulan orang- orang yang berbobot guna memenuhi kebutuhan-kebutuhan di masa yang akan datang. Jadi agar pengembangan karier berjalan dengan baik, maka harus diciptakan keselarasan antara perencanaan karier yang dilakukan oleh pegawai dengan manajemen karier yang diterapkan oleh organisasi.

\section{Tinjauan Pustaka}

\section{A. Landasan Empiris}

Ada beberapa penelitian yang terdahulu tentang pengaruh pengembanga karier terhadap kepuasan kerja dari para peneliti yang mendukung penelitian ini.Farantika Agnes Dwi Ambarwati (2017) dalam jurnal Riset Mahasiswa Manajemen (JRMM) ISSN: 2337-5655. Volume: 3, Nomor: 1dengan judul Pengaruh Pengembangan Karier Terhadap Kepuasan Kerja Karyawan Di Pt. Kusuma Satria Dinasasri Wisatajaya Batu. Hasil penelitian menunjukkan bahwa :Secara bersama-sama variabel pengembangan karier berpengaruh signifikan terhadap 
kepuasan kerja karyawan di PT. Kusuma Satria Dinasasri Wisatajaya.Vendriana Lisdiani (2017) dalam jurnal Diponegoro Journal Of Social And Political Science tahun, Hal 1-8 dengan judul Pengaruh Pengembangan Karier Terhadap Kepuasan Kerja Karyawan Melalui Motivasi Kerja Sebagai Variabel Intervening (Studi Kasus Pada Hotel Grasia Semarang). Hasil analisis menggunakan uji model dan uji mediasi terdapat pengaruh pengembangan karier terhadap kepuasan karyawan melalui motivasi kerja telah terbukti signifikansi. Novitri Nilam Sari (2016) dalam jurnal eJournal Administrasi Bisnis, 4 (2) 2016 : 620 - 630 dengan judul Pengaruh Pengembangan Karier Terhadap Kinerja Karyawan PT Pln (Persero) Wilayah Kalimantan Utara Sektor Pembangkit Mahakam Samarinda. Hasil penelitian menunjukkan bahwa Pengembangan Karier berpengaruh positif signifikan terhadap Kinerja karyawan.

\section{B. Pengembangan Karir}

Pengembangan karier merupakan upaya pribadi seorang karyawan dalam mewujudkan rencana kariernya, perwujudan ini bias didukung atau tidak didukung oleh departemen SDM. Berikut cara cara yang dapat dan biasa digunakan karyawan untuk mengembangkan karier.

- Kinerja; prestasi kerja adalah hal utama yang harus ditunjukkan oleh setiap karyawan bilan ingin membangun kariernya dengan baik dan mulus.

- $\quad$ Exposure; pandai mempromosikan diri pada saat yang tepat.

- Levergaging; permintaan berhenti untuk melanjutkan pekerjaan di perusahaan lain sering kali digunakan karyawan untuk membangun karier yang lebih baik.

- Dedikasi; kesetiaan jangka panjang biasanya lebih dihargai dalam perbaikan karier

- Mentor dan sponsor : mentor adalah orang yang menawarkan bimbingan karier informal, sedangkan sponsor adalah orang dalam organisasi yang dapat menciptakan kesempatan pengembangan karier bagi orang lain.

- Edukasi; pendidikan, latihan, dan kursus tambahan yang bertujuan menambah keahlian serta ketrampilan karyawan dengan sertifikat yang mendukung akan membantu karier seseorang.

\section{Variabel Pengembangan Karir}

Kriteria keberhasilan karier telah mengalami perubahan.Pada orientasi trasdisional keberhasilan karier dimaknai sebagai model yang stabil dalam mencapai jenjang karier di satu lini profesi atau di satu perusahaan ataukelompok perusahaan.Menurut Shellenbarger, 2010 beberapa indikator selalu muncul sebagai faktor penentu keberhasilan karier, yaitu sebagai berikut :

- Keterampilan semasa belajar

- Keahlian

- Pelatihan ulang

- Kemampuan mendapatkan pekerjaan secara berkesinambungan

- Keberhasilan psikologis

\section{Kepuasan Kerja}

Pada dasarnya kepuasan kerja karyawan merupakan hal yang bersifat individual, setiap individu akan memiliki tingkat kepuasan yang berbeda-beda sesuai dengan system nilai yang berlaku pada dirinya. Biasanya orang akan puas dengan pekerjaan yang dijalaninya, apabila apa yang telah dikerjakannya sesuai dengan apa yang diharapkan, sesuai dengan tujuan ia bekerja .Menurut Robbins: kepuasan kerja adalah suatu sikap umum seorang individu terhadap pekerjaannya. Mangkunegara, Prabu, Umar (2007) menyatakan faktor-faktor yang mempengaruhi kepuasan kerja adalah faktor karyawan dan faktor pekerjaan.

Luthans menyatakan kepuasan kerja adalah hasil dari persepsi karyawan mengenai seberapa baik pekerjaan mereka memberikan hal yang dinilai penting.Terdapat tiga dimensi yang diterima secara umum dalam kepuasan kerja.Pertama, kepuasan kerja merupakan respon emosional terhadap situasi kerja.Kedua, kepuasan kerja sering ditentukan menurut seberapa baik hasil yang dicapai memenuhi atau melampaui harapan.Ketiga, kepuasan kerja mewakili beberapa sikap yang berhubungan.

\section{Metodologi}

Penelitian ini dilaksanakan di kota Malang yaitu karyawan dari Alfamart di Malangsebagai populasinya, dan sebanyak 50 orangmenjadi sampel penelitian. Pengembangan karir pada dimensi keterampilan semasa belajar, keahlian,pelatihan ulang, kemampuan mendapatkan pekerjaan secara berkesinambungan dan keberhasilan psikologissebagai variabel bebas serta kepuasan kerja sebagai variabel terikat. Analisis data yang digunakan adalah analisis regresi linear berganda.

\section{Pembahasan}

\section{A. Analisa Data}

Berdasarkan analisis yang dilakukan, bahwa data-data yang didapat dari jawaban responden berasal dari kuesioner yang disebarkan. Hasil analisis deskriptif untuk sampel yang diteliti karakteristik responden sebagian besar responden adalah laki-laki dengan jumlah 30 responden (60\%), sedangkan untuk perempuan berjumlah 20 responden (40\%). Data karakteristik responden berbasis usia paling banyak pada kisaran hingga 25 tahun dengan jumlah sebanyak 26 orang (52\%), disusul responden berusia 26 - 30 tahun sebanyak 12 orang (24\%) dan sisanya sebanyak 8 responden (16\%) berusia 31-40 tahun serta 4 responden (8\%) berusia lebih dari 40 tahun.

Penaksiran koefisien regresi pada analisis ini menggunakan metode kuadrat terkecil (ordinary least square). Penerapan metode ini akan menghasilkan sebuah penaksiran yang baik jika seluruh asumsi yang berlaku dalam analisis bisa terpenuhi. Asumsi yang mendasari pada analisis regresi antara lain: tidak terjadi multikolinier, tidak terjadi heteroskedastisitas dan nilai residual berdistribusi normal. 
Tabel 1. Hasil Pemeriksaan Multikolinier

\begin{tabular}{|l|c|c|}
\hline \multicolumn{1}{|c|}{ Variabel } & Tolerance & VIF \\
\hline $\begin{array}{l}\text { X1. Keterampilan semasa } \\
\text { belajar }\end{array}$ & 0,570 & 1,754 \\
\hline X2. Keahlian & 0,857 & 1,167 \\
\hline X3. Pelatihan ulang & 0,598 & 1,672 \\
\hline $\begin{array}{l}\text { X4. Kemampuan } \\
\text { mendapatkan pekerjaan } \\
\text { secara berkesinambungan }\end{array}$ & 0,648 & 1,544 \\
\hline $\begin{array}{l}\text { X5. Keberhasilan } \\
\text { psikologis }\end{array}$ & 0,980 & 1,021 \\
\hline
\end{tabular}

Hasil pemeriksaan terhadap asumsi tidak terjadi multikolinier dilakukan dengan menghitung nilai Variance Inflation Factor (VIF) pada variabel bebas. Gujarati (1995) berpendapat bahwa sebuah variabel bebas akan dianggap memiliki multikolinieritas yang tinggi dengan satu atau beberapa variabel bebas lainnya jika nilai VIF > 10. Dari hasil perhitungan dapat ditarik kesimpulan bahwa pada data tidak terjadi multikolinieritas karena seluruh nilai VIF yang didapat adalah kurang dari 10 .

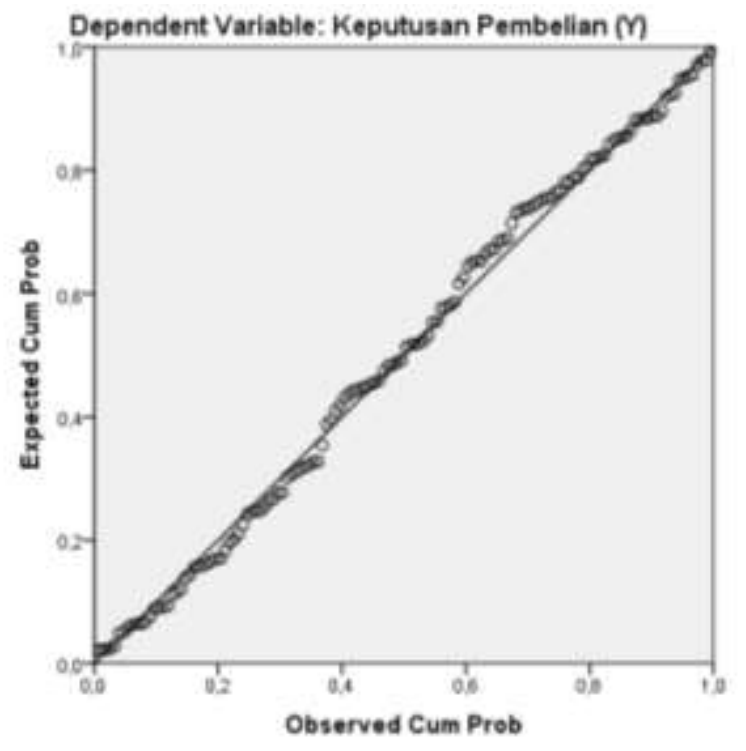

Gambar 1. P-P Plot Uji Kenormalan Data Residual

Pembuktian bahwa nilai residual (error) menyebar normal merupakan salah satu indikasi persamaan regresi yang diperoleh adalah cukup baik. Artinya dengan pembuktian ini dapat disimpulkan bahwa peluang mendapatkan nilai residual sekitar nol adalah lebih besar daripada nilai peluang yang jauh dari angka nol. Pembuktian kenormalan nilai residual dilakukan dengan menggunakan uji Kolmogorov-Smirnov. Dari hasil perhitungan diperoleh nilai $Z_{\text {hitung }}$ sebesar 0,686 yang lebih kecil dari $Z_{\text {tabel }}=1,96$ dan $p$-value $=0,734$ yang lebih besar dari $\alpha=0,05$.

Uji normalitas dilakukan dengan memperhatikan diagram pencar P-P plot. Pemeriksaan distribusi normal pada data residual dengan menggunakan P-P plot ditunjukkan dengan hasil pencaran data yang akan membentuk satu garis lurus diagonal, dan ploting data residual akan dibandingkan dengan garis diagonal. Jika distribusi data residual normal, maka garis yang menggambarkan data sesungguhnya akan mengikuti garis diagonalnya. Pada gambar diatas tampak bahwa pencaran data telah mendekati garis lurus.

Tabel 2. Pemeriksaan Heteroskedastisitas

\begin{tabular}{|l|c|c|}
\hline \multicolumn{1}{|c|}{ Variabel } & $\begin{array}{c}\text { Koefisien } \\
\text { regresi }\end{array}$ & p-value \\
\hline X1.Keterampilan semasa belajar & 0,022 & 0,907 \\
\hline X2. Keahlian & 0,060 & 0,492 \\
\hline X3. Pelatihan ulang & 0,299 & 0,057 \\
\hline $\begin{array}{l}\text { X4. Kemampuan mendapatkan } \\
\text { pekerjaan secara berkesinambungan }\end{array}$ & $-0,238$ & 0,055 \\
\hline X5. Keberhasilan psikologis & 0,025 & 0,776 \\
\hline
\end{tabular}

Asumsi selanjutnya adalah pemeriksaan terhadap tidak terjadinya heteroskedastisitas. Heteroskedastisitas akan mengakibatkan penaksiran koefisien-koefisien regresi menjadi tidak efisien. Hasil penaksiran akan menjadi kurang dari semestinya. Heteroskedastisitas bertentangan dengan salah satu asumsi dasar analisis jalur, yaitu bahwa variasi residual adalah sama untuk semua pengamatan atau disebut homoskedastisitas. Prosedur uji yang digunakan untuk mendeteksi gejala heteroskedastisitas adalah dengan uji Glejser dengan menghitung koefisien korelasi antara nilai mutlak residual terhadap seluruh nilai variabel bebas. Jika nilai p-value pada hasil uji-t terhadap koefisien regresi lebih besar dari $\alpha=0,05$, maka dapat dikatakan bahwa tidak terjadi gejala heteroskedastisitas pada nilai residual. Hasil yang ditunjukkan Tabel 2, dapat ditarik kesimpulan bahwa asumsi tidak terjadi heteroskedastisitas dapat terpenuhi.

Tabel3. Hasil Perhitungan Regresi

\begin{tabular}{|l|c|c|c|}
\hline \multicolumn{1}{|c|}{ Variabel } & Beta & T & P-value \\
\hline $\begin{array}{l}\text { X1.Keterampilan semasa } \\
\text { belajar }\end{array}$ & 0,318 & 2,336 & 0,024 \\
\hline X2. Keahlian & 0,005 & 0,046 & 0,964 \\
\hline X3. Pelatihan ulang & 0,276 & 2,072 & 0,044 \\
\hline $\begin{array}{l}\text { X4. Kemampuan } \\
\text { mendapatkan pekerjaan } \\
\text { secara berkesinambungan }\end{array}$ & 0,285 & 2,232 & 0,031 \\
\hline X5. Keberhasilan psikologis & 0,030 & 0,289 & 0,774 \\
\hline
\end{tabular}

$\mathrm{R}=0,731 ;$ Adjusted $\mathrm{R}^{2}=0,482 ; \mathrm{R}^{2}=0,534 ;$

$\mathrm{F}=34,654 ; P=0,000$

Analisis regresi berganda digunakan untuk menggambarkan bentuk pengaruh antara variabel independen (bebas) terhadap variabel dependen (terikat). Hal-hal penting dalam analisis regresi antara lain : persamaan regresi, koefisien determinasi terkorelasi $\left(\mathrm{R}^{2}\right.$ adj), hasil uji-F dan uji-t.Dari persamaan regresi diketahui bahwa variabel terikat keputusan pembelian (Y) nilainya akan diprediksi oleh keempat variabel bebas. Koefisien regresi pada seluruh variabel bertanda positif, hal ini bisa dimaknai bahwa semua unsur berpengaruh positif terhadap keputusan pembelian.

\section{B. Pengujian Hipotesis}

Pengujian hipotesis untuk mengetahui apakah hasil pengolahan data sampel dapat digeneralkan untuk populasi. Analisis regresi digunakan untuk memprediksi hubungan kausal antara sejumlah variabel bebas dan variabel terikat. Pengambilan keputusan untuk pengujian hipotesis digunakan nilai signifikansi (p) dengan kriteria apabila 
$\mathrm{p}>0,05$, maka $\mathrm{H}_{0}$ diterima atau $\mathrm{H}_{\mathrm{a}}$ ditolak, artinya koefisien regresi yang diperoleh adalah tidak signifikan, Dan apabila $\mathrm{p}$ $<0,05$ maka $\mathrm{H}_{0}$ ditolak atau $\mathrm{H}_{\mathrm{a}}$ diterima, artinya koefisien regresi yang diperoleh adalah signifikan.

Hipotesis H1 dinyatakan bahwa diduga variabel keterampilan semasa belajar, keahlian,pelatihan ulang, kemampuan mendapatkan pekerjaan secara berkesinambungan dan keberhasilan psikologis secara simultan berpengaruh signifikan terhadap kepuasan kerja. Hasil uji-F terhadap kontribusi pengaruh secara bersamasama (simultan) dari keempat variabel bebas terhadap kepuasan kerja sebesar 10,104 adalah signifikan $(\mathrm{p}=0,000)$, sehingga dapat disimpulkan bahwa data penelitian mendukung hipotesis $\mathrm{H} 1$ bahwa keterampilan semasa belajar, keahlian, pelatihan ulang, kemampuan mendapatkan pekerjaan secara berkesinambungan dan keberhasilan psikologis secara simultan berpengaruh signifikan pada kepuasan kerja.

Hipotesis H2 dinyatakan bahwa diduga variabel keterampilan semasa belajar, keahlian,pelatihan ulang, kemampuan mendapatkan pekerjaan secara berkesinambungan dan keberhasilan psikologis secara parsial berpengaruh signifikan terhadap kepuasan kerja. Hipotesis ini terkait dengan limahasil uji koefisien regresi yang ada di dalam persamaan regresi. Hasil uji-t terhadap koefisien regresi pada hubungan keterampilan semasa belajar terhadap kepuasan kerja sebesar 0,318 adalah signifikan $(p=0,024)$. Hasil uji-t terhadap koefisien regresi pada hubungan keahlian terhadap kepuasan kerja sebesar 0,005 adalah tidak signifikan $(\mathrm{p}=0,964)$. Hasil uji-t terhadap koefisien regresi pada hubungan pelatihan ulang terhadap kepuasan kerja sebesar 0,276 adalah signifikan ( $\mathrm{p}=$ 0,044).Hasil uji-t terhadap koefisien regresi pada hubungan kemampuan mendapatkan pekerjaan secara berkesinambungan terhadap kepuasan kerja sebesar 0,285 adalah signifikan $(\mathrm{p}=0,031)$. Pada kelima hasil uji-t, seluruh koefisien adalah signifikan, sehingga dapat disimpulkan bahwa data penelitian mendukung hipotesis $\mathrm{H} 2$.

Hipotesis H3 dinyatakan bahwa pengembangan karir berdasarkan keterampilan semasa belajar berpengaruh dominan terhadap kepuasan kerja. Koefisien regresi untuk keterampilan semasa belajar adalah terbesar pertama setelah variabel kemampuan mendapatkan pekerjaan secara berkesinambungan. Sehingga dapat disimpulkan bahwa data penelitian mendukung hipotesis H3 bahwa keterampilan semasa belajar berpengaruh dominan terhadap kepuasan kerja.

\section{Penutup}

Hasil analisis dan pembahasan yang ada dari penelitian ini menghasilkan beberapa kesimpulan antara lain:

1. Pengembangan karir berpengaruh signifikan terhadap kepuasan kerja. Kepuasan kerja tergolong tinggi karena mampu dibentuk oleh pengembangan karir yang tepat.

2. Secara parsial, pengembangan karir pada kelima komponen yaitu keterampilan semasa belajar, keahlian, pelatihan ulang dan kemampuan mendapatkan pekerjaan secara berkesinambungan berpengaruh signifikan terhadap kepuasan kerja. Koefisien beta paling tinggi bersumber dari pelatihan ulang.

3. Pengembangan karir dari keterampilan semasa belajar terbukti menjadi faktor penentu dominan terhadap kepuasan kerja.

4. Pengembangan karir pada komponen kemampuan mendapatkan pekerjaan secara berkesinambungan berpengaruh dominan terhadap kepuasan kerja.

\section{RUJUKAN}

[1] Ambarwati, F. A. (2017). Pengaruh pengembangan karir terhadap kepuasan kerja di pt kusuma batu. jurnal riset mahasiswa manajemen (JRMM), Vol 3 No 1.

[2] Aumman, g. e. (2009). Time are changing gender and generation at work and at home. new york: NY Families.

[3] Gary, d. (2013). Human Resource Management edisi ke 3. London: Pearson.

[4] Hook, f. m. (2011). Introducing human resource management. London: prentice.

[5] Huat, d. g. (2009). Human Resource Management an asian perspective edisi ke 2. Singapura: Pearson.

[6] J.A, 1996, Executive relocations and hassles increase . the wall street journal , hlm B8.

[7] Kuncoro, 2010, Prosedur penelitian, Jakarta, Penerbit Rieneka Cipta.

[8] Lisdiani, V, 2017, Pengaruh pengembangan karir terhadap kepuasan kerja karyawan melalui motivasi sebagai variabel interverensi (studi kasus pada hotel grasia semarang),Diponegoro journal of social dan politic science .

[9] Sari, N, 2017, Pengaruh pengembangan karir terhadap kinerja karyawan pt pln persero wilayah kalimantan utara sektor pembangkit mahakam samarinda, Ejournal Administrasi Bisnis.

[10] Shellenbarger, 2010, When your co-worker is your spouse. the wall street journal, hlm B1,B4.

[11] Sikula, 2007, Personnel administration and human resource management. Santa Barbara: John Wiley and Sons.

[12] Slovin, 2008, Metode Penelitian Bisnis. Jakarta, Penerbit Gramedia.

[13] Sugiyono, 2014, Metode Penelitian Kualitatif dan Kuantitatif, Jakarta : Graha Mulia.

[14] Suranto, P. D, 2009, Riset Bisnis, Yogyakarta, Penerbit Graha Ilmu.

[15] Wayne, C, 2013, Managing Human Resource productivity quality of worklife profits, Edisi ke 9. New York: Mcgrawhill. 